\title{
研究報告
}

\section{溶湯直接混合法（プレミックス法）により製造された シラス発泡体／アルミニウム複合材の性質についで*}

\author{
長田 純夫** ・上野 英俊** ・今川 耕治** \\ 北原 晃 ${ }^{* *}$. 秋山茂**
}

On the properties of the shirasu (a kind of volcanic ash) balloons/aluminum composite prepared by mechanical mixing method (the pre-mix method)*

UDC:669. 71+549.514. 5:621.74.04

NAGATA Sumio**, UENO Hidetoshi**, IMAGAWA Koji**, KITAHA Akira** and AKIYAMA Shigeru**

Two processes "pre-pack method" and "pre-mix method" are applicable to produce fine hollow grains of volcano glass-aluminum composites (SBAG in short). The former includes packing the glassy grains in a die cavity and squeeze-casting molten aluminum. The latter includes mechanically pre-mixing the grains and molten aluminum and press-forming the slurry mixture in a die cavity. Properties of this composite having low density produced in the latter process were determined comparing with those produced in the former process. Test items were metallurgical structure, specific gravity, volumertic fraction of the grains, tensile, compressive, and impact strengths, thermal and electrical resistances, and thermal expansion.

(Received April 15, 1976)

\section{1. 緒言}

火山ガラス微細中空球のシラス発泡体 ${ }^{1)}$ (以下その英 文の頭文字を取り S B と略記する) とアルミニウムと の複合材 (以下その英文 Shirausu Balloons-Aluminum Composite の頭文字を取り SBACと略記する) は, 主と して, プレパック法2)，すなわち型内に充填された S B 集合体閒隙を溶融金属で満たしSBACを得る方法，およ びプレミックス法 ${ }^{3)}$, すなわち $\mathrm{SB}$ と溶融アルミニウムの 混合相を型内に流し込み SBACを得る方法, により製造 することができる。しかし， S B と溶融アルミニウムと の混合相の流動性はほぼ無に等しく, 各種試験片を作製 することが困難であつたため，プレミックス法で得られ たSBACの諸性質はこれまで検討されなかつた。そこで 今回は, 機械擋拌機装置により得られた S B とアルミニ ウムの混合相をプレス利用の成形装置により棒状に成形 し，この棒試料から種々の試験片を切り出し，プレミッ クス SBACの機械的, 物理的性質を調べた。得られた結 果はプレパック SBACのそれらと比較検討された。

\section{2. 実験方法}

\section{1 複合素状}

金属素材には市販の鋳造用 $12 \% \mathrm{Si}-\mathrm{Al}$ 合金を, S B に は粒径範囲 $105 \mu \mathrm{m} \sim 590 \mu \mathrm{m}$, 比重0.46のものを用いた。

\section{2 混合}

比重が極めて小さい S B と溶解アルミニウム合金を混 合してもその比重差のために上下に分離すると予想され るが，ある種の条件下では混合が可能となる(この分 離, 混合表象については別の機会に報告する)。

Fig. 1 は混合装置の概略図である。電気炉(A)で所定温 度に保持された黒鉛製円筒状るつぼ(B)内に, 他の電気炉 で溶解された Al-12\% Si 合金(C)約700 g を移す。溶湯温 度が安定した後，三枚四段羽根ミキサー(D)を 1,000 r.p. m. で回転し, 同時に $\mathrm{SB}(\mathrm{E})$ 用ホッパー(F)の弁 $(\mathrm{G})$ を開く と, SB と溶融アルミニウムが混合し, 溶融 SBAC が得ら れる。S B 投入速度は弁により調節され, 平均投入速度 は50 cc/min であつた。また, S B の全投入量は金属量 に対し体積比で 4 対 6 であつた。擋拌を停止すると，余

* 軽金属学会第50回春期大会 $(51-2)$ にて発表した。

** 九州工業技術試験所(鳥栖市)。National Industrial Research Institute of Kyushu (Tosu). 


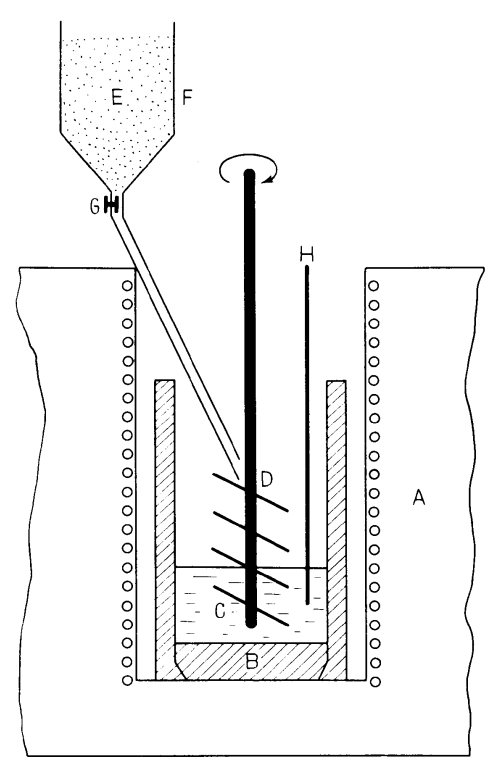

A: Furnace, B: Graphite crucible, G: Molten metal, D: Mixer, E: Shirasu Balloons, F: Hopper, G: Valve, H: Thermo couple

Fig. 1 Scematic drawing of the apparatus used for mixing molten $\mathrm{Al}-12 \% \mathrm{Si}$ alloy with Shirasu Balloons.

㮃の金属分がるつぼの底に沈降するので，この投入量比 は得られる SBAC の SB対金属の割合には直接関係はな い。熱電対(H)で混合前後の温度を試料ごとに測つたが, 温度変化はほとんど見られなかつたので電気炉の温度調 節により混合温度を管理することができた。

\section{3 溶解 SBAG のるつほからの流出}

溶解 SBACの流動性はほとんど無に等しく,るつぼを 傾けても余剩の金属分が流出するだけで $\mathrm{SBAC}$ は中に留 まつている。これを流出させるためにるつぼの構造を Fig. 1 亿示寸ように, 円筒部および底部から成るように した。底板にはテーパがつけてあるので, 下方へ抜け落 ちない。るつぼを傾け, 底板を出口の方へ押し出すと, るつぼ内の溶解 SBAC は強制的に流出される。

\section{4 成形}

2 個の独立した油圧ユニットを有するプレスを利用し て棒試料成形装置を製作した。Fig. 2 はその概略図であ る。シース型埋入ヒータ $(\mathrm{A}) て ゙ 300^{\circ} \mathrm{C}$ 亿予熱された加圧室 (B)内に，2.3に記述された方法で溶融 SBAC (C)を注入 し，上方ラムに取り付けられた成型金型(D)を押し下げる と SBAC は金型内のキャビティを満たす。キャビティ内 の空気は型先端に設けられた空気抜き(F)を通じて外部へ 逃げる。凝固後に下方ラムを下げて型抜きを行ならと, $20 \mathrm{~mm} \phi \times 190 \mathrm{~mm}$ の棒試料が得られる。

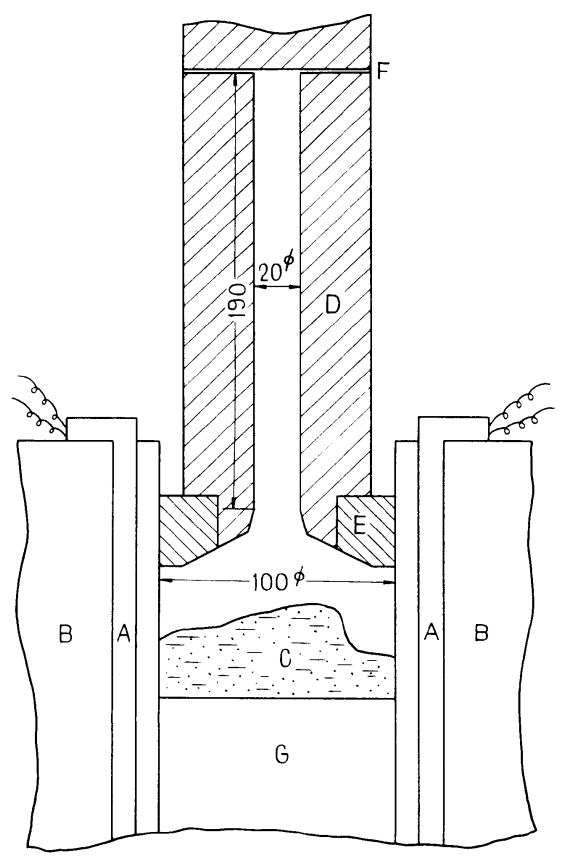

A: Heater, B: Pressure chamber, C: Molten SBAC, D: Mold, E: Graphite die, F: Air vent, $\mathrm{G}$ : Lower ram

Fig. 2 Schematic drawing of the apparatus used for shaping the pre-mixed SBAC into a rod.

\section{5 試料作製条件}

SBAC 材質に及ぼす要因は種々考えられるが，予備実 験により成形圧以外は顕著な効果を示さなかつたので， $\mathrm{S} \mathrm{B}$ と金属の投入量比を体積比で 4 対 6 , 混合温度を $670^{\circ} \mathrm{C}$ ，擋拌時間を 5 分，ラム降下速度を $5 \mathrm{~cm} / \mathrm{sec}$ ，に それぞれ固定し，成形圧を $6.4 ， 2.7 ， 19.1$ ，および 25.5 $\mathrm{kg} / \mathrm{cm}^{2}$ の 4 種類とした。成型圧が低過ぎると金型キャビ ティを完全に満たす再現性が悪くなり，一方，高過ぎる と S B の静水圧破壊が増大するので, 上記のような範囲 を採用した。

なお，比較のためのプレパック板材 $(100 \mathrm{~mm} \times 100$ $\mathrm{mm} \times 10 \mathrm{~mm})$ の製造条件は, S B 予熱温度 $200^{\circ} \mathrm{C}, \mathrm{Al}-$ $12 \% \mathrm{Si}$ 合金の注入温度 $800^{\circ} \mathrm{C}$, 成型圧 $30 \mathrm{~kg} / \mathrm{cm}^{2}$ であつ た。

\section{3. 結果および考察}

\section{1 組織}

Photo1 は作製試料の外観である。加圧室に注入後の 温度降下を緩和するために必要量以上の溶融 SBACを用 いたので，試料棒にはかなりの押し残り部分が付いてい る。

Photo 2 は棒状部のマクロ組織である。外皮の白い部 


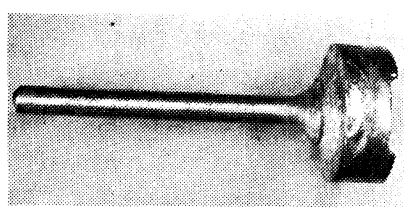

Photo 1 Appearance of the SBAG formed into a rod.

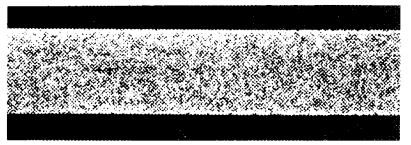

Photo 2 Macrostructures in the longitudinal cross section of the rod sample. $((\times 3 / 4) \times 4 / 7)$

分は金属相で，型壁に沿ら流体は金属分に富んでいるこ とを示している。これは，溶融金属とS B では壁との摩 擦係数に明らかな差異があるので，当然の結果であろ 5。この外皮部を除けば組織はマクロ的にほぼ均一であ り，均一性においてプレパック法に劣るものではないこ とがわかる。

Photo 3(a) は Photo 2 に示される試料から任意に選ば れた固体のミクロ組織である。写真が示すよらに破壊し たS B 㸺状部にほんどみられず，S B 破壊率はプレパ ック法より低い。ただし，押し残り部の隅角部や底辺に は, Photo3 (b), (c) のような静水圧破壊 ${ }^{2}$ や一軸圧縮破 壊4)が一部観察された。

\section{2 比重}

Fig. 3 は試料棒先端から根元へかけての比重分布の一 例である。比重は初め徐々に増加し, 根元部で急増して いる。S Bの破壊は比重の高い部分でも観察されなかつ たので S B 体積分率と関係しているものと思われる。こ のことについては次節で詳しく述べる。

試料棒中心から半径方向へ外側に向から比重分布の一 例が Fig. 4 に示される。各データ点は試料を約 $0.5 \mathrm{~mm}$ ずつ旋盤で削り，そのつど重量を測定することにより算 出された。中心から約 $8 \mathrm{~mm}$ まではほぼ均質とみなすこ

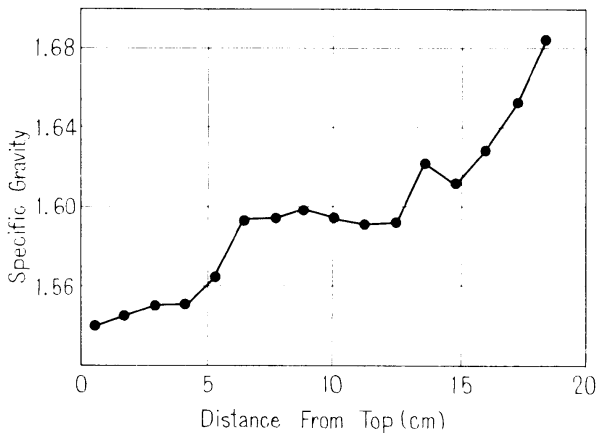

Fig. 3 Variation of specific gravity along the rod axis.

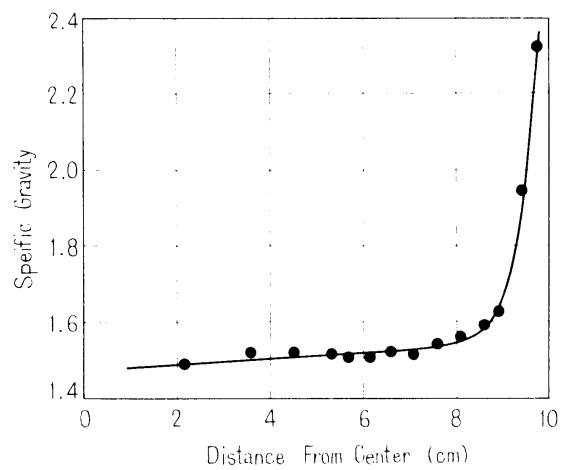

Fig. 4 Variation of specific gravity along the radial direction.

よができるが，川周部に近ゔくにつ机比重は急増してい る。これはPhoto 2 に示されたよらに，試料外皮部がほ 上んど金属相から成つているからである。

外皮部を除いたプレミックス材の比重は 1.48 1.50 で，同じ素材から得られたプレパック材のそれ（1.40） と比較してやや高い。これも S B 体積分率に関係してい る。

\section{3. $3 \mathrm{~S} \mathrm{~B}$ 体積分率}

点分析により試料先端から根元へかけての S B 体積分率

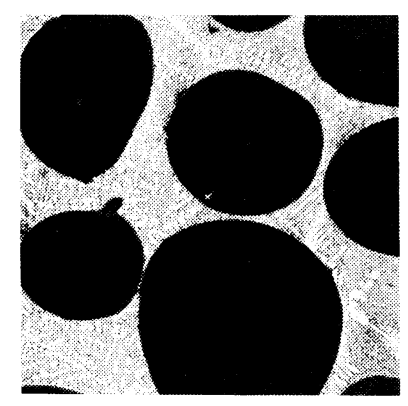

(a) Normal

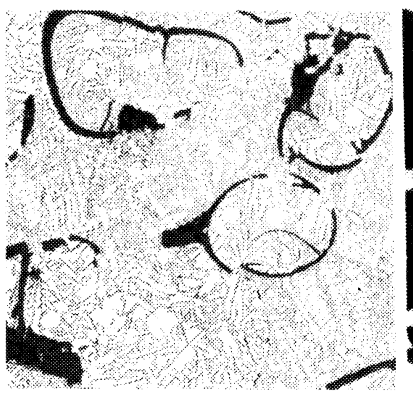

(b) Fractured hydrostatically

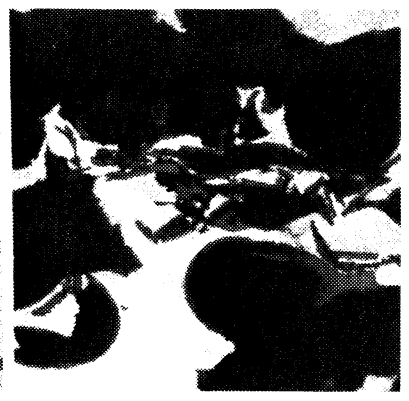

(c) Fractured uniaxially

Photo 3 Microstructures of the SBAC prepared by the pre-mix method $((\times 100) \times 6 / 7)_{2}$ 
を測定して Fig. 5 が得られた。比重分布と対比させるた めに縦軸には金属の体積分率を採つている。Fig. 3 の比 重分布とFig. 5の金属分率分布はよく似た傾向を示して いるので，どちらか一方で他を推測することが可能であ る。S B および素地金属の比重を0.46および2.61として, $\mathrm{SBAC}$ の比重 $\mathrm{d}$ 金属体積分率 $\mathrm{V}_{V}^{M}$ の関係を複合則から 求めると(1)式が得られ，実測値とよく一致した。

$$
d=2.15 V_{V}^{M}+0.46
$$

棒試料根元部で, 比重, したがつて金属分率が急増し ている理由を明らかにするために, 試料全体の中心軸に 沿ら金属分率を測定するとFig. 6 のような分布曲線が得 られた。S B と溶融金属の混合相では金属分率の高いほ ど流動度は高いと考えられるので, Fig. 6 から判断すれ ば棒根元部が最も流動度は高いことになる。このことは 金型形状を考慮すると次のように説明することができ る。

溶融 SBAC は Fig. 2 に示された金型のダイスで絞ら れる結果, 棒試料根元部で最大の加速度をもつて 流れ る。押出しの場合ダイス部における流速の変化は物質の

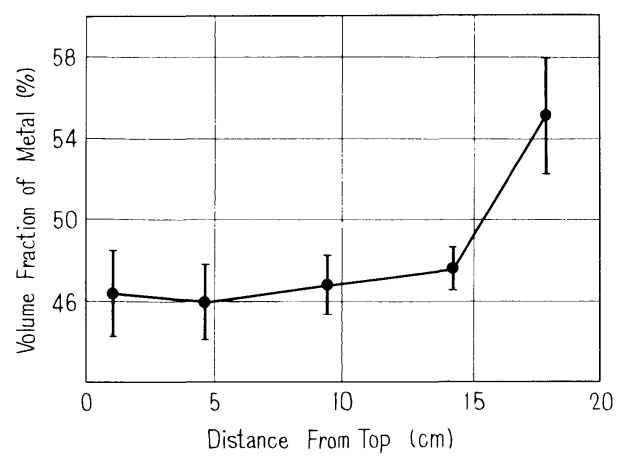

Fig. 5 Variation of metal fraction along the rod axis.

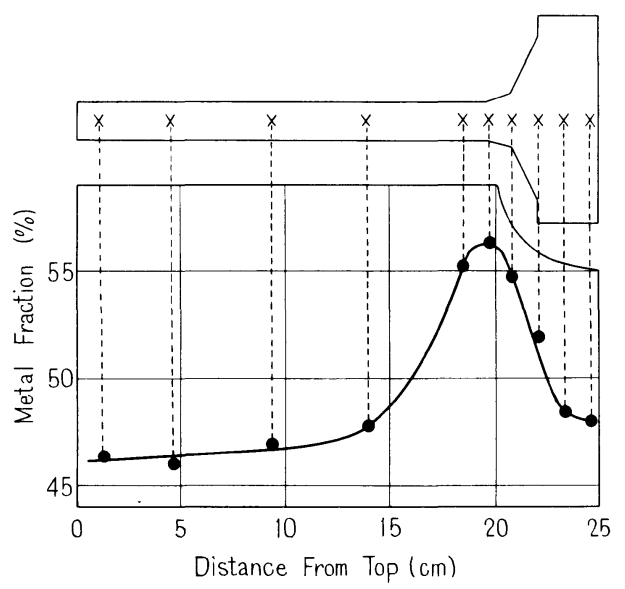

Fig. 6 Distribution curve of metal fraction along the rod axis.
相対移動によつてなされるので, 加速度最大部が相対移 動度も最大とみなすことができる。また，ダイス壁に接 した溶融SBACの流れは, 棒状キャビティ壁に沿ら流れ と同ように金属相に富むので，これらの集中する棒根元 部は金属分率が高くなることを助長されている。

\section{4 引張り強さ}

棒試料を 2 本に切断し，そのまま引張り試片に供し た。Fig. 7 は引張り強さ，およびそれを比重で除した比 引張り強さと成形圧との関係である。いずれの試料もプ レパック材の強さ (約 $\left.4.0 \mathrm{~kg} / \mathrm{mm}^{2}\right)$ より高い值を示し, こ れはプレミックス材がプレパック材より金属分率が高い こと, 成形試料をそのまま試片にしたため外皮金属相の 影響を受けていること，などの理由によるものと思われ る。

\section{5 圧縮強さ}

$10 \mathrm{~mm} \phi \times 10 \mathrm{~mm}$ の円柱状試片を試料から削り出し 圧縮試験を行なつた結果, Fig. 8 が得られた。眓には比

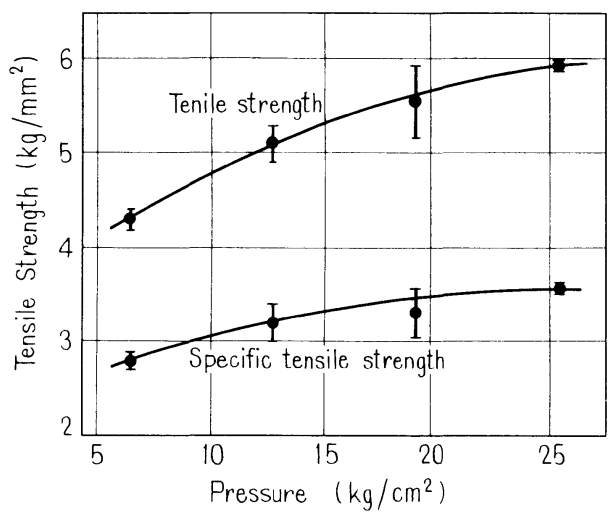

Fig. 7 Tensile strength of SBAC prepared by the pre-mix method vs. forming pressure.

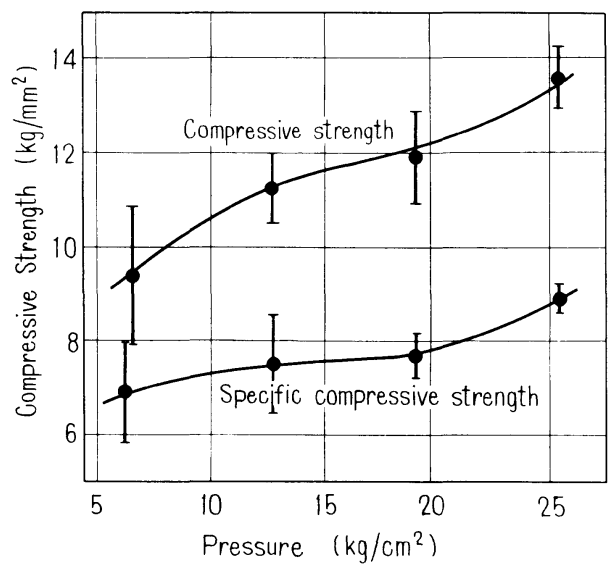

Fig. 8 Compressive strength of SBAC prepared by the pre-mix method vs. forming pressure. 
重で除した比圧縮強さも併記してある。両者とも成形圧 と共に増大するのは引張り強さの場合と同様である。

圧縮強さもプレミックス材がプレパック材 $(11.3 \mathrm{~kg} /$ $\left.\mathrm{mm}^{2}\right)$ よりわずかながら優れていると言える。

\section{6 衝撃值}

JIS で指定されているノッチなしシャルピー試片を棒 試料から削り出し徵撃試験を行なつた結果はFig. 9 に示 される。データの分散度も大きく, 成型圧の効果も明確 に現われず，プレパック材 $(12.3 \mathrm{~kg} \cdot \mathrm{cm})$ とプレミック 材との差異もほとんどない。

\section{7 電気抵抗}

直径 $5 \mathrm{~mm}$ の棒状試片を棒試料から削り出し, 電位差 法により電気抵抗を測定した。Table 1 にプレミックス 材，プレパック材，およびデータブックから取られた素 地金属の電気比抵抗 $\rho$ の各值を揭げる。表には比抵抗の 他に，電気伝導度（比抵抗の逆数） $1 / \rho$ および(2)式を用 いて計算される電気伝導度 $(1 / \rho)_{C}$ を掲げた。

$$
(1 / \rho)_{C}=\frac{1}{2} V_{V}^{M}(1 / \rho)^{M}
$$

ここで $V_{V}^{M}$ は複合材の金属体 積分率， $(1 / \rho)^{M}$ は金属自 身の電気伝導度である。 $\mathrm{SBAC}$ の電気伝導度は金属分率 と共に増加するのは当然であるが，(2)式の計算ともよく 一致している。(2)式の誘導はステレオロジーの基礎式 ${ }^{5)}$, および結晶ネットワークモデルを用いてなされたが，詳 細は別の機会に報告する。

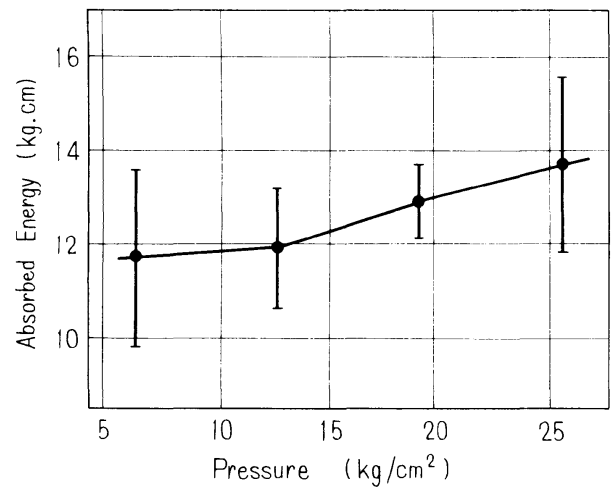

Fig. 9 Impact value of SBAC prepared by the pre-mix method vs. forming pressure.

Table 1 Specific electric resistance, $\rho$, electric conductivity, $1 / \rho$, and calculated electric conductivity, $(1 / \rho)_{c}$.

\begin{tabular}{l|c|c|c}
\hline \multicolumn{1}{c|}{ Specimen } & $\rho(\mu \Omega \cdot \mathrm{cm})$ & $\begin{array}{c}1 / \rho \\
(1 / \mu \Omega / \mathrm{cm})\end{array}$ & $\begin{array}{c}(1 / \mu)_{c} \\
(1 / \mathrm{cm})\end{array}$ \\
\hline Pre-mixed SBAC & 1.80 & 0.557 & 0.555 \\
Pre-packed SBAC & 2.10 & 0.476 & 0.492 \\
Al-12\%Si alloy & 0.44 & 2.26 & - \\
\hline
\end{tabular}

Table 2 Comparison of the properties of the SBAC's prepared by the pre mix and the prepack method.

\begin{tabular}{|c|c|c|}
\hline Properties & $\begin{array}{r}\text { Pre-mixed } \\
\text { SBAC }\end{array}$ & $\begin{array}{r}\text { Pre-packed } \\
\text { SBAC }\end{array}$ \\
\hline Spcific gravity & 1.50 & 1.40 \\
\hline $\begin{array}{l}\text { Volume fraction of Shirasu } \\
\text { Balloons }\end{array}$ & 0.52 & 0.60 \\
\hline Tensile strength $\left(\mathrm{kg} / \mathrm{mm}^{2}\right)$ & 5.5 & 4.0 \\
\hline $\begin{array}{l}\text { Specific tensile strength } \\
\left(\mathrm{kg} / \mathrm{mm}^{2}\right)\end{array}$ & 3.7 & 2.9 \\
\hline $\begin{array}{l}\text { Compressive strength } \\
\left(\mathrm{kg} / \mathrm{mm}^{2}\right)\end{array}$ & 11.9 & 11.3 \\
\hline $\begin{array}{l}\text { Specific compressive strength } \\
\left(\mathrm{kg} / \mathrm{mm}^{2}\right)\end{array}$ & 7.9 & 7.4 \\
\hline Impact value $(\mathrm{kg} \cdot \mathrm{cm})$ & 12.9 & 12.3 \\
\hline $\begin{array}{l}\text { Specific electric resistance } \\
(\mu \Omega \cdot \mathrm{cm})\end{array}$ & 1.8 & 2.1 \\
\hline $\begin{array}{l}\text { Thermal coductivity } \\
\left(\mathrm{cal} / \mathrm{cm} / \mathrm{sec} /{ }^{\circ} \mathrm{C}\right)\end{array}$ & $9.0 \times 10^{-2}$ & $6.8 \times 10^{-2}$ \\
\hline $\begin{array}{l}\text { Coefficient of linear } \\
\text { expansion }\left(1 /{ }^{\circ} \mathrm{C}\right)\end{array}$ & $1.89 \times 10^{-5}$ & $1.80 \times 10^{-5}$ \\
\hline
\end{tabular}

\section{8 熱伝導度}

$10 \mathrm{~mm} \times 10 \mathrm{~mm} \times 1.5 \mathrm{~mm}$ の板状試片にレーザーを 照射し，その間の温度上昇から熱定数を求める, いわゆ るレーザーフラッシュ法により熱伝導度を測定した。そ の結果, プレミックス材に対して $0.090 \mathrm{cal} / \mathrm{cm} / \mathrm{sec} /{ }^{\circ} \mathrm{C}$, プレパック材に対して，0.068 cal $/ \mathrm{cm} / \mathrm{sec} /{ }^{\circ} \mathrm{C}$ とら值が 得られた。(2)式と同様な計算式を当てはめると，これ

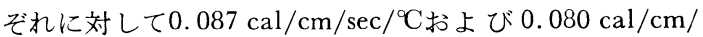
ec $/{ }^{\circ} \mathrm{C}$ といら数值が得られ，実測值とほぼ一致した。

\section{9 熱膨張係数}

$3 \mathrm{~mm} \phi \times 5 \mathrm{~mm}$ の円柱状試片を温度制御方式高周波 加熱装置により加熱冷却し, $300^{\circ} \mathrm{C}$ ま゙の平均線膨張係数 を求めると，プレミックス材に対して $1.89 \times 10^{-5} /{ }^{\circ} \mathrm{C}$, プレパック材に対しては $1.80 \times 10^{-5} /{ }^{\circ} \mathrm{C}$ とら值が得ら れた。プレミックス材の方が少し高い值を示すのは金属 分率の差に基づくものと思われる。

以上, プレミックス材の諸性質を調ベた。プレパック 材との比較を容易にするために表にまとめると Table 2 のようになる。

\section{4. 結言}

プレミックス法により得られた SBACの諸性質を測定 し，プレパック法により得られた SBACの材質と比較検 討した結果，次のような知見を得た。

(1) プレミックス材もプレパック材に劣らぬ均一な $\mathrm{SB}$ 分布を示す。

（2） SBAC 中の SB 破壊率はプレミックス法による方 
がプレパック法によるよりむしろ低い。

(3) S B 体積分率はプレミックス材がプレパック材よ り数パーセント低い。

(4) プレミックス材とプレパック材との性質の差異は ほとんどなく数值に数パーセントの差があるだけであ る。この差は SBAC 中の SBまたは金属分率の差異に起 因している。

（5） SBAC の電気伝導率 $1 / \rho$ は理論的に

$$
1 / \rho=\frac{1}{2} V_{V}^{M}(1 / \rho)^{M}
$$

で表わされ，実測值とよく一致した。ここで $V_{V}^{M} は$ SBAC の金属体積分率, $(1 / \rho)^{M}$ は金属の電気伝導率を
示す。

\section{参考 文 献}

1) 木村, 陣内, 諫山：割業協会誌, 80 (1972), 84 .

2) 長田, 今川, 北原, 秋山, 上野, 徳広 : 軽金属, 23 (1973), 303.

3) 今川, 長田, 北原, 秋山, 上野, 徳広 : 軽金属, 23 (1973), 282.

4) 秋山, 今川, 長田, 北原, 上野, 徳広 : 軽金属 26 (1976), 219.

5) R. T. De-Hoff and F. N. Rhines: Quantitative Microscopy, McGraw-Hill, (1968), 78. 